\title{
Research Support in Theological Libraries (1)
}

by Pauline Allen
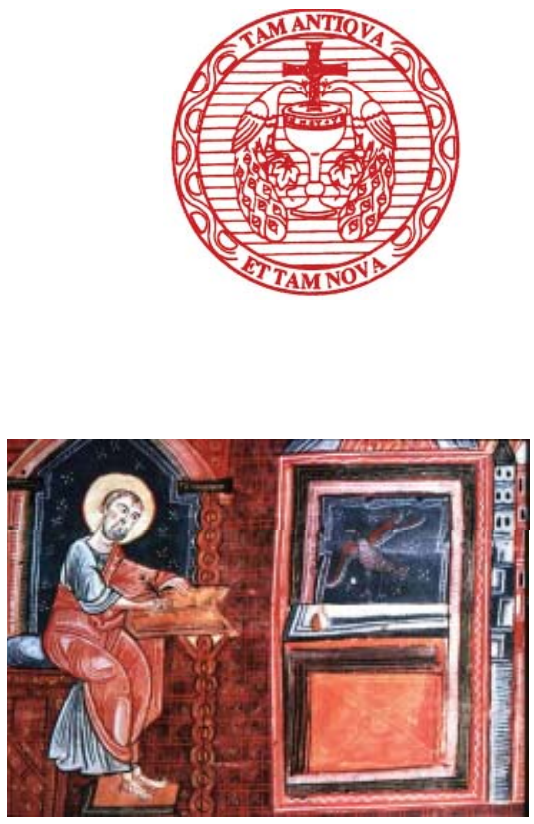

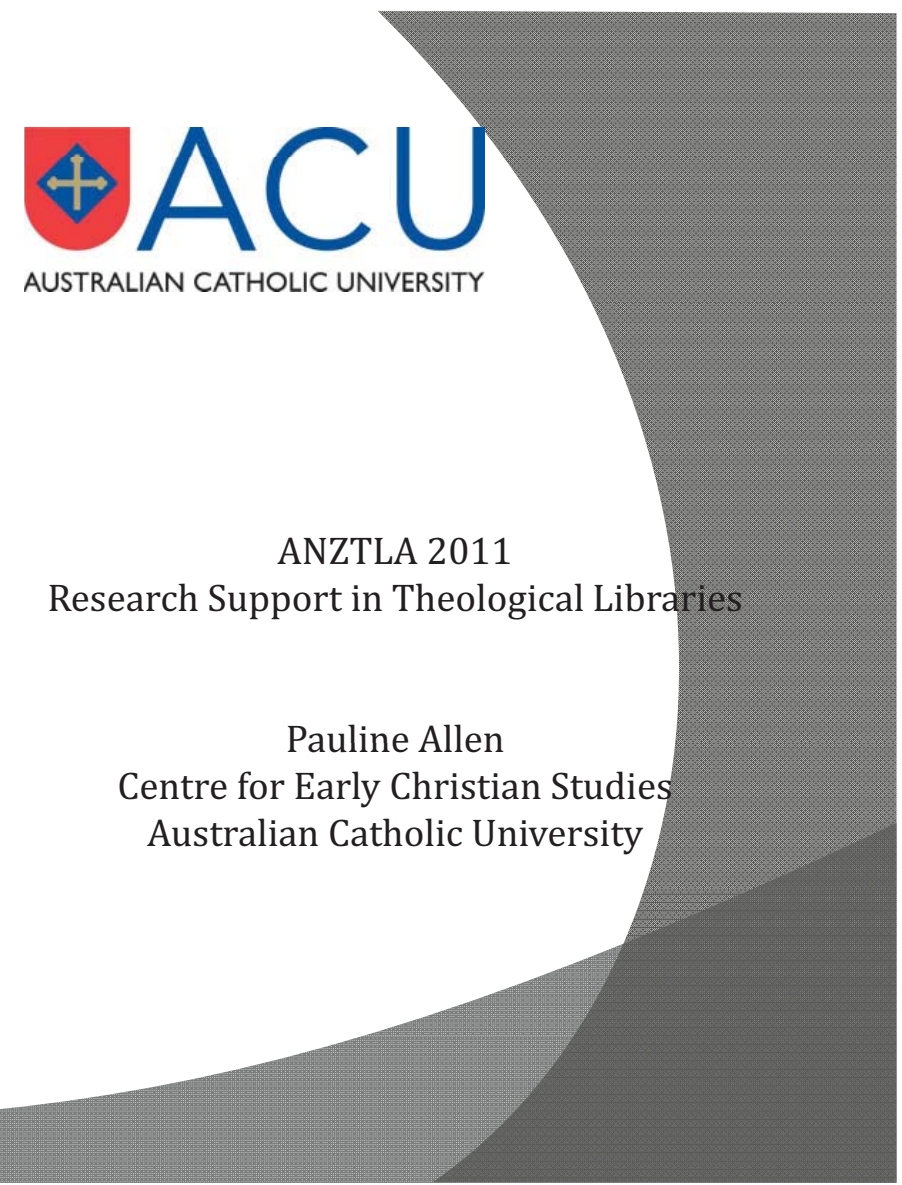




\section{Objectives of the Centre}

○ to foster and develop the systematic study of early Christian literature from the first to the eighth century, in the areas of history, philosophy, theology, ethics, politics and social issues

○ to conduct and publish research of an international standard

( ) to provide leadership and advice to the University and other tertiary institutions, on matters pertaining to Early Christian Studies

o to liaise and co-operate with other Centres in relevant fields

○ to seek and raise funds from appropriate sources for research and related activities

\section{Funded Research}

Crisis management in late antiquity: the evidence of Episcopal letters

ARC Discovery Project 2010-2012 (Pauline Allen and Bronwen Neil) $\$ \mathbf{2 6 2 , 0 0 0}$

The Clash of Sacred and Secular Authority in the Letters of Innocent I

ARC Australian Research Fellowship 2007-2012 (Rev. Dr. Geoffrey D. Dunn) \$534,000

Poverty and Welfare in Late Antiquity

ARC Discovery Project: 2006-2008 (Pauline Allen, Wendy Mayer and Bronwen Neil) $\$ \mathbf{3 2 0 , 0 0 0}$ Dwelling in the Household of God: The Spirituality of the Fourth Gospel.

ARC Discovery Project: 2004-2006 (Mary Coloe) \$102,500

- The development of the cult of Mary in North African Christianity (100 - 431 C.E.).

ARC Discovery Project Grant: 2003-2005 (Pauline Allen, assisted by Geoffrey Dunn) \$210,000

Popes and Martyrs: The Politics of Hagiography in Ninth-Century Rome.

ARC Postdoctoral Fellowship: 2001-2005 (Bronwen Neil) \$210,000

John Chrysostom: A Revisionist approach to a Prominent Figure in Late Antiquity. ARC Queen Elizabeth II Fellowship: 2001-2005 (Wendy Mayer) \$370,943

- Completing the picture of a vital historical source: The homilies of John Chrysostom. ARC Large Grant: 2001-2003 (Wendy Mayer, assisted by David O'Brien and Silke Trzcionka) $\$ 121,461$

- The bishop as letter-writer: pastoral care and civic administration in Christian antiquity. ARC Large Grant: 2000-2002 (Pauline Allen, assisted by Geoffrey Dunn and Youhanna Nessim Yousseff) $\$ 111,234$

- Edition and translation of documents pertaining to the life of Maximus Confessor. ARC Large Grant: 1999-2001 (Pauline Allen, assisted by Bronwen Neil) \$134,609 The Homilies of John Chrysostom: Rehabilitating a vital late antique historical source. ARC Postdoctoral Fellowship: 1998-2000 (Wendy Mayer) \$171,737

John Chrysostom and Severus of Antioch as bishops, preachers and letter writers: Pastoral care and civic administration in Late Antique culture.

ARC Large Grant: 1998-2000 (Pauline Allen, assisted by Kathleen Hay) \$91,416 


\section{OBSERVATIONS}

1. Nature of the research and its difficulties

i. secondary materials in foreign languages

ii. old and out-of-print books

e.g. G. Przychocki, De Gregorii Nazianzeni epistulis quaestiones selectae (Cracow 1912)

iii. limited access to ebooks

iv. unwilling libraries/suppliers

v. financial aspects

\section{OBSERVATIONS}

2. Strategies for research support

i. winning competitive research grants

ii. advocacy with senior library staff and DVC Research

iii. donations 


\section{OBSERVATIONS}

3. Nexus between acquisition and interlibrary loans

\section{OBSERVATIONS}

4. Manuscript acquisition

i. Greek Latin, Coptic, Arabic, mediaeval French

ii. microfilm/microfiche/photocopy

iii. unreliable catalogues/suppliers

iv. financial aspects 